\title{
Mumbai slums and the search for 'a heart': Ethics, ethnography and dilemmas of studying urban violence.
}

\author{
By Atreyee Sen (Department of Anthropology, School of Oriental and \\ African Studies, University of London).
}

In this article, I have explored some of the methodological problems faced by anthropologists when they conduct fieldwork in volatile ethnographic settings. My own fieldwork was based in the slums of Mumbai, one of the commercial capitals of India, where working-class women had allied themselves with a violent, Hindu nationalist movement. The 'fundamentalist' women, who had organised themselves into a miltant, semi-religious task force, played a vital role in orchestrating urban riots. While living and working with these women, I found myself a helpless, often frightened bystander to various forms of factional 'war'. Would, should, could I prevent this overt use of violence and threats? That was always my primary dilemma. The eerie spectre of ethics continued to haunt my work during the writing-up stage, even though I was far, far away from my killing fields. In this article, I have tried to highlight and address some of the dilemmas of studying urban conflict, in a bid to emotionally equip future research scholars studying the anthropology of violence.

Uprooted from her 'green' village, forced to settle into an urban slum in Mumbai (Bombay) with her labourer husband, Tarabai was repeatedly raped by her employer before pay day. Now a woman in her late 70s, she always sang songs from old Hindi films...

Kahi building, kahi tram-ey

Kahi motor, kahi mill,

Milta hain yeha sab kuch,

Par milta nahi dil,

Zara hatkey, zara bachkey,

Yeh hain Mumbai, meri jaan...

Building, and trams,

And motors and mills,

You get everything here.

Yet you can't find a heart,

Be careful, save yourself,

This is Mumbai my dear.

Recently widowed, Tarabai was once a leading member of a Hindu fundamentalist party that supported women's militancy. She remembers street-fights with members from the 'other' communities - Hindus, Muslims, 'secular people', migrants and so 
forth - and still recalls some old sentimental songs that she hums while listening to the radio. As she sang I sat in her shack whose walls were made of tin plates and a plastic sheet that passed for a roof. I, the anthropologist, had come to 'make sense' of her life, and learn why young and old women in Mumbai slums became Hindu nationalists and engaged in collective, communal violence and urban conflict.

Although the paper does not discuss the rise of female militancy within Hindu fundamentalism in urban India, I must provide some context to my concerns. Since the 1920s, Hindu fundamentalism has given rise to numerous front organisations, which have engendered local, political, social and religious insecurities for many years. One such organization is the Shiv Sena, a regional political party (named after a Hindu martial king Shivaji). For several decades, the Shiv Sena was content with regionalism, asserting the cultural superiority of native people in the Indian state of Maharashtra and claiming economic and political power for them. However it later developed nationalistic aspirations and decided to move 'from region to religion'. The party turned towards Hindutva, a movement that fervently upholds Hindu nationalism in India.

For a year I worked with some low income, working class women who allied themselves with the Shiv Sena in Mumbai, the capital of Maharashtra. I interpreted the actions and ideas of the Shiv Sena women's front, the Mahila Aghadi, and traced how these women transformed themselves from a behind-the-scenes, subservient support group to a militant, partially autonomous women's task force. I focused on the circumstances and experiences of those slum women who were instrumental in creating and maintaining communal tensions, particularly during the Hindu-Muslim Bombay riots of 1992-93. On a daily basis, the Sena women engaged in various forms of collective violence in the name of delivering 'social justice'. They thrashed eveteasers ${ }^{1}$, attacked rapists, chided men who abandoned their wives, hassled businessmen into employing poor women and demonstrated in front of employers who had not paid salaries on time. Their rationale: group violence was a means for securing women's honour, mobility and productivity in the Mumbai slums. Nevertheless female militancy needs a gloss of religious legitimacy, hence the Sena women paid lip service to the Hindu nationalist movement.

\title{
Methodology and studying violence
}

\begin{abstract}
'As anthropologists we try, I think, to recapitulate our experiences of primary disorientation and of trying to find our feet in a place where our common sense assumptions about the world take us exactly nowhere... But the "setting" eventually becomes populated with people you grow to know, sometimes to love, sometimes to dislike, almost always to respect. The gray house down the street becomes not just any gray house; it was Tanoue-san's home, where I might be invited for tea, if I happened by at the right time' (Kondo 1990:7).
\end{abstract}

Some time before setting out for my field, I planned structure for my work in my head. I called it my 'methodology'. However from the day I stepped off a train at Dadar station in Bombay and my bag snapped open letting my specially-tailored saffron-coloured 'Hindutva' salwar kameezes tumble onto the platform, I knew that

\footnotetext{
${ }^{1}$ Men who harass women in public places.
} 
nothing would be under my control. And things never were. However, over time the city of Mumbai, its slums and the Sena families did become familiar and comprehensible to me through the process of doing research. Accordingly the hovel in the corner became Tarabai's 'home' where I went to listen to the radio in the evening, chew betel nuts and hear stories about her life.

To begin with I met academics, journalists, police officials, NGO workers, hospital attendants, criminals and Sena sympathisers to get the pulse of the city and make myself familiar with the operations of the Mahila Aghadi. I met my informants in restaurants, their homes, on train platforms, in psychiatric wards, in their offices, on the road, on the beach, in secret spots behind local bars. However my attempts to approach the Sena through Bal Thackeray, the party supremo, proved futile and he dismissed me as a 'Bengali researcher rat, who would collect data in one way and write something else about the Sena'. I was defeated by his accurate insight.

To collect my data, I posed as a staunch Hindu fundamentalist and successfully acquainted myself with the Shiv Sena women's wing. I accompanied the women everywhere they went in the city. Lived with them in their slums for a whole year, sat in their demonstrations, walked in their protest marches, watched their social service activities; I talked, ate, drank, played mischief, smoked surreptitiously and took part in their recreational activities. The women introduced me into a city that I never knew and which they thought was theirs and had the right to rule. I went with the women when they took to the streets and stood watching as they set Abu Azmi's effigies on fire (Azmi was a Muslim corporator of the Samta Party, the new name for the old Muslim League, who made 'anti-India' statements on record). I watched Sena women corporators attack and strip two Muslim women corporators in the House of Parliament, and then ate ice-cream with them on the beach, went home and helped during dinner, played with their children and grandchildren. Now I loved them, now I hated them. Occasionally I was an insider, occasionally I was an outsider, but I was always an observer. An observer who saw the discrepancies in the women's personalities, who saw both the street fighter and the loving wife and mother. And as I watched I saw my structure and research methodology disperse.

\section{Covert research and ethical issues}

My fieldwork with the Sena women could be described as 'covert urban research'. This gave rise to several paradoxes and grave ethical dilemmas. Unlike several anthropologists working among lower classes, I did not wear a physical disguise to be part of the community. But I did wear a mask of being a Bengali, Hindu upper caste woman who had come from London to uncover the Aghadi's successes. I reassured the Sena women that I was not going to side with their victims (as most people did), since I wanted to study the ideas and actions of the aggressors. I also convinced the women that I had come to the slums to learn from poor women and not to preach. I showed humility and wonder at their achievements. The women allowed me to be a part of their urban women-criminal-political nexus. After getting settled in the slums, when I asked 'disturbing' questions about violence, secularism or feminism, the women assumed that my queries flowed from my class difference with them. I did not 'know'. I never told the women about my own ideological beliefs. They did not ask.

Researching a criminalised group had some serious consequences. I was always haunted by the thought that my work came at a price: the price of betraying the 
victims of violence. In my case, the perpetrators wished to communicate through the anthropologist to the world that existed beyond the slums. They wanted to convey some part of the experience of the passion of violence, its necessity, its benefits, its normalisation and its immediacy. I made every effort to be fair to the Sena women and their circumstances. However in doing so I represented just one side of the ongoing arguments concerning justice, revenge, forgiveness and freedom, and my work does not discuss the victims of the Bombay riots or their impotence while watching the Sena women wreak havoc and display their power. I also spent my waking hours wondering whether I was cheating or compromising these women; especially when they would look at me for approval after thrashing a 'deviant' person in public. Many of the women I worked with wanted the power to punish and kill. I was present during their displays of violence and realised that within their particular section of the city they felt equal to any other law-enforcing organisation. Accordingly much of my work is clouded by my fear of the women and my desire to safeguard the possibility of returning to Bombay, a city I could not help but love. I chose the easiest path into their lives by not telling the women that I had different political convictions. But I also had the most difficult path out. For when I left the slum, the women told me that they would kill me and my family, if I ever breathed a word against them.

This raises another important implication of covert research. There is always a question of personal security. I did not know that I was tailed by a Sena 'detective' for days before I was allowed to live in the slums. He informed the women that I 'drank with men in cheap pubs', 'smoked long cigarettes', 'rented a flat in Bandra where boys came', 'met secular journalists and academics'. I was grilled on these activities. I then stopped going to my flat, stopped smoking, quit drinking and did not keep in touch with anybody outside the slums for months. Everyone was convinced that I was dead.

There were often small explosions in the slums when 'country-made' bombs would explode and I became jumpy after seeing the open use of guns and knives. These concerns took up a lot of mental energy and I had to repeatedly tell myself to be 'brave' and 'show courage'. While attending an all-party meet at Sena Bhavan, the Sena women bundled me into a cab and asked me to lie low for a few days. I was perplexed. When I returned to the slums, I was informed that I had 'caught the naughty eye' of a senior Sena leader. I realised that it is important for a researcher in the field to be emotionally or physically equipped to protect themselves at all times. I felt I did not keep that distance from the Sena women and whilst this made my ethnography richer it made my life poorer. A researcher who lived partially in fear of her subjects.

Time and experience also took its toll on my convictions and left me feeling confused and exhausted. Sections of Sena women had developed a strong-arm image and adopted a philosophy of brute justice to secure redress for women. This proved to be far more efficient and inexpensive for women in the slums than normal systems of legal justice. While I was living in the slums, a Sena leader, Rita, called me and asked whether I would go with the women to a local school, where a clerk had been consistently harassing a teacher. I arrived a little late and was directed to the school premises. When I walked into the office, I saw this clerk kneeling on the floor, with Rita, perched on his desk, occasionally poking a measuring scale into his testicles. The man flinched in pain. He was made to apologise to the teacher several times, and then had to say 'this teacher is my sister' and 'all women are my sisters'. After this 
entire drama was over, the Sena cadres left in a hurry. Before she sailed out of the room, Rita yelled: 'Make sure you are not a sister-fucker!'

This event greatly hurt my sensibilities and I stood around speechless for a while.

A few days later, while traveling to Central Bombay to meet another Sena woman leader, I was followed by an 'eve-teaser'. I stopped at a shop and asked for directions to this Aghadi leader's house. The 'eve-teaser' turned pale and to my relief ran as fast as his legs could carry him. This event did not offend my sensibilities in the least and I cheerily rattled off the story to the Sena leader when I finally found her residence. However there is a purpose in elaborating this dilemma. For the Sena women collective violence and rough justice was a prerequisite for the survival of underprivileged women living in the city. Moreover its 'benefits' were also enjoyed by the anthropologist. 'So I am right and you were wrong, you admit?' the Aghadi leader asked me. 'But violence cannot assure long-term solutions' I insisted. 'Who will live that 'long'?' she mocked me. 'Those women out there?' She looked out of the window at the sprawling slums and her eyes rested on a woman drinking water from a dirty hole in the ground.

Most of the time I did not intervene when the women were 'in action', probably slapping a man with their rubber slippers. I was afraid that I would hurt myself and in the process lose their trust. I would often look around at the milling crowds on the streets of Bombay. People had merely stopped to stare. They were terrified of the Aghadi women. The policemen standing around would give me sheepish grins if we made eye contact. Either they supported the Aghadi or were simply bribed into silence.

Yet I did intervene. Once.

When I went to the slums, I was prepared to see violent women. I was not equipped to see small children turning violent to encourage and emulate their mothers. The Sena children operated a 'kids gang' in Mumbai and it had developed their own 'line of attack' towards enemy communities. I did step in when a Sena children's gang tried to attack a Muslim baker passing through a Sena-dominated slum. 'We are letting you go only because of Didi (elder sister, as the children liked to call me),' a boy warned the baker. Just for a day, just for a while, I felt I had suspended notions of cultural relativism and objective ethnography and climbed down from the role of 'the noninterventionist anthropologist'.

It was difficult to write about people's experiences of violence and it has been difficult to present a description of violence, for writing on violence implicates one in a contradiction: to retain the authenticity of an account, even though it is highly disturbing, without offending the sensibilities of the reader. Kondo (1990), while studying how selfhood is constructed in a Japanese industrial and familial setting, argues that the liveliness and complexity of everyday life cannot be encompassed by theoretical models which rely on organisational structures, 'typical' households and referential meanings. 'And to examine that complexity and richness in its specificity leads towards a strategy that expands notions of what can count as theory, where experience and evocation can become theory, where the binary between the 'empirical' and the 'theoretical' is displaced and loses its force' (1990:8). Whilst in the slums and afterwards in my writing, I have tried to move away from critical and theoretical perspectives, towards a more aesthetic appreciation of the lives, of the circumstances and the violence in the lives of Sena women and children. 
It has also been difficult to forget the women and children I feared and adored. When I came away, a woman I worked with very closely was shot dead. A massive fire in Kherwadi slums burned down several shacks and killed eight children, maybe I had stayed with them. I did not know whether writing on the spectacle of violence, death and destruction had any value. A friend of mine put things in perspective for me: 'When you are in the field, you are a part of things out there. When you return, the field carries on without you.'

When in the slums, I took on the responsibility of taking stories from the narrow existential reality of my informants and communicating them to a wider world that lies far beyond the city. Through their construction of me as a friend, a sympathiser and an agent of the bhari duniya, the wider world, did they also construct an image of the duniya that would support their aggression? I always felt too guilty to ask what they expected in return for my year-long stint with them. When preparing to leave the slums, I went to Tarabai's shack and asked her why she told me about her life. She sang:

Dil ka haal suney dilwala,

Sidhi si baat na mirch masala,

Kehkey rahega kehneywala...

Only those with a good soul will listen to the tales of my heart,

Simple words, without any spices,

Those who wish to tell all, will rest only after they have spoken...

\section{References}

Hansen, T.B. 2002. Wages of violence: identity in post colonial Bombay. Princeton: Princeton University Press

Kondo, D.K. 1990. Crafting selves: power, gender and discourses of identity in a Japanese workplace. Chicago: Chicago University Press.

Kosambi, M. 1986. Bombay in transition: the growth and social ecology of a colonial city, 1880-1980. Stockholm, Sweden: Almqvist \& Wiksell International.

Lele, J. 1995. Saffronisation of the Shiv Sena. in Bombay: Metaphor for Modern India. (eds) Sujata Patel and Alive Thorner. Bombay: OUP.

Patel, S. and Jim M. (ed). 2003. Bombay and Mumbai: The city in transition. New Delhi: OUP.

Seabrook, J. 1987. Life and labour in a Bombay slum. London: Quartet.

Subbayya, R. 1986. An ethnolinguistic survey of Dharavi, a slum in Bombay. Mysore: Central Institute of Indian Languages.

\section{About the author}

Atreyee Sen is part-time lecturer and post-doctoral research assistant at SOAS, University of London. She has recently completed her $\mathrm{PhD}$ dissertation entitled 
'Women and Communal Violence in India: A Countervictimology; A Case Study of Hindu Fundamentalist Women in Maharashtra'. Her areas of interest are gender, children, migration and communal conflict in South Asia. 